\title{
ANALISIS ASPEK KEMASYARAKATAN MELALUI PEMIKIRAN A. SAMAD SAID DALAM NOVEL DAERAH ZENI DAN HUJAN PAGI
}

\author{
MOHD FIRDAUS CHE YAACOB * \\ firdaus.cy@umk.edu.my*
}

\begin{abstract}
Abstrak
Kajian ini dijalankan untuk menganalisis aspek kemasyarakatan melalui pemikiran oleh A. Samad Said dalam novel popular beliau yang bertajuk Daerah Zeni dan Hujan Pagi. Hal ini kerana aspek kemasyarakatan yang dibincangkan dalam novel oleh A. Samad Said dapat menggambarkan kekuatan pemikiran pengarang melalui kreativiti beliau yang dapat memberi sumber maklumat terkini kepada khalayak atau pembaca. Oleh itu, kajian ini juga dijalankan bertujuan mengenal pasti dan menganalisis aspek kemasyarakatan melalui pemikiran A. Samad Said dalam novel Daerah Zeni (1985) dan Hujan Pagi (1992). Di samping itu, reka bentuk kajian ini bersifat kualitatif melalui kaedah kepustakaan dan analisis kandungan teks. Selain itu, teori sosiologi dijadikan sebagai deduktif untuk memantapkan analisis perbincangan. Sebagai kesimpulannya, hasil dapatan kajian ini membuktikan bahawa A. Samad Said bijak mengutarakan cetusan idea dan kreativiti dalam usaha membincangkan isu semasa yang dapat diterima secara terbuka oleh masyarakat di dalam novel popular beliau.
\end{abstract}

Kata Kunci: A. Samad Said, Kemasyarakatan, Novel, Pemikiran, Teori Sosiologi 


\title{
ANALYSING THE SOCIETAL ASPECTS THROUGH THE THINKING OF A. SAMAD SAID IN THE NOVEL DAERAH ZENI AND HUJAN PAGI
}

\author{
MOHD FIRDAUS CHE YAACOB * \\ firdaus.cy@umk.edu.my*
}

\begin{abstract}
This study was conducted to analyze the aspects of society through the thinking by A. Samad Said in his popular novel titled Daerah Zeni and Hujan Pagi. This is because the societal aspects discussed in the novel by A. Samad Said can illustrate the strength of the author's thinking through his creativity which can provide the latest sources of information to the audience or readers. Therefore, this study was also conducted by aiming at identifying and analyzing the aspects of society through the thinking by A. Samad Said in the novels Daerah Zeni (1985) and Hujan Pagi (1992). This study is qualitative in nature by using the library methods and text content analysis. In addition, sociological theory is used deductively to strengthen the analysis of the discussion. This study has proven that A. Samad Said has wisely expressed the spark of ideas and creativity in an effort to discuss current issues that can be openly accepted by the community in his popular novel.
\end{abstract}

Keywords: A. Samad Said, Societies, Novel, Thought, Sociological Theory

\footnotetext{
Senior Lecturer at Faculty of Creative Technology and Heritage, Universiti Malaysia Kelantan, Malaysia
} 


\subsection{Pengenalan}

Bidang kesusasteraan membuka ruang kepada penulis untuk melahirkan daya kreatif dan sensitiviti berdasarkan pemikiran dan pengalaman ke dalam bentuk karya. Hasil karya yang baik mempunyai nilai-nilai berunsur kebudayaan yang mampu mempengaruhi minda dan jiwa pembaca. Oleh sebab itu, karya sastera sebahagian daripada seni dan seni itu cabang dari kebudayaan yang dapat menarik minat orang ramai untuk turut berkecimpung di dalamnya. Dalam menginterpretasikan maksud dan mesej sesebuah karya memerlukan tumpuan dan tindak balas daripada pembaca kerana tidak mudah mengenal pasti budaya sesuatu bangsa. Menurut pendapat Kamaruzzaman A. Kadir (1985) kesusasteraan adalah segala hasil ciptaan manusia melalui bahasa yang bersifat seni. Sebagai hasil seni, maka ciri utamanya mengandungi emosi, imaginasi dan budi. Selain itu, Danziger dan Johnson (1991) berpendapat bahawa kesusasteraan secara luas merupakan seni yang menggunakan kata-kata tanpa memperhitungkan persoalan sama ada kata-kata itu tertulis atau diucapkan. Dalam menjelmakan pemikiran, seseorang penulis dapat menyampaikan cetusan-cetusan berupa buah fikiran, perasaan, harapan, cita-cita dan impian serta dapat mewujudkan hubungan yang erat sesama manusia dalam dunia persekitarannya. Sehubungan dengan itu, dalam setiap penghasilan kesusasteraan akan melihat kecenderungan pengarang menggambarkan atau menceritakan kehidupan secara khusus untuk menggambarkan sebuah kehidupan manusia dan kemanusiaan berlandaskan pegangan kebenaran serta kejujuran sebagai keindahan hidup yang sempurna. Dalam konteks ini, dengan melihat kepada setiap hasil karya yang telah dihasilkan, pengarang akan meletakkan sepenuh jiwa raga, emosi dan pengalaman hidupnya untuk menyampaikan sesuatu mesej yang sangat berguna kepada masyarakat di muka bumi yang penuh dengan pancaroba ini.

Dalam konteks kemasyarakatan, kesusasteraan bukan semata-mata karya untuk ditatap dan dibaca, malahan merupakan sebuah alat pengukur kepada nilai dalam masyarakat. Menurut Suminto (2000), kesusasteraan merupakan sebahagian daripada masyarakat kerana dalam sastera terdapat banyak perkara yang boleh dipelajari. Selain itu, kesusasteraan juga merupakan sebuah wadah untuk mendidik masyarakat dan sekali gus memasyarakatkan segala bidang dan disiplin ilmu (Fathin Noor Ain dan Ramli Azhar Wahid, 2018). Hal ini demikian kerana, tidak ada bidang yang tidak boleh dihujah dan dibincangkan seperti seperti yang terdapat dalam bidang sastera. Oleh itu, dapatlah disimpulkan bahawa kesusasteraan dalam konteks kemasyarakatan merupakan sebuah jalinan yang perlu dalam masyarakat dalam usaha untuk terus mempelajari dan memperbaiki setiap kesilapan sosial melalui kajian terhadap kesusasteraan.

Menerusi tajuk kajian ini berketepatan dengan sosiologi dalam novel, maka analisis kajian ini akan membincangkan sosiologi mengikut aspek agama, sosial dan ekonomi. Hal ini kerana pengarang mampu menggarap idea dalam mengutarakan penulisan dalam karyanya. Oleh hal yang demikian, dua buah novel yang dikaji iaitu novel Daerah Zeni dan Hujan Pagi ini merupakan bahan kajian yang dipilih untuk dilihat dalam aspek sosiologi.

\subsection{Sorotan Kajian}

Pertamanya, Halis Azhan Mohd.Hanafiah (2014) dalam kajian Dinamika Tema dalam Novel Remaja di Malaysia meneliti dinamika tema dalam novel remaja di Malaysia, bermula dari 
tahun 1950-an hingga tahun 2000-an. Kajian ini dijalankan hasil pemahaman tema dalam novel remaja dipengaruhi oleh berbagai-bagai peristiwa yang berlaku dalam masyarakat. Antaranya ialah pengaruh pendidikan yang kian berkembang sejajar dengan perkembangan dunia, perubahan dasar kerajaan dalam bidang sosial, ekonomi dan politik, masalah-masalah dalam penerbitan buku, peranan badan kerajaan dan bukan kerajaan, peranan pendidik, ahli politik, dan sasterawan, masalah kegawatan sosial remaja, kepentingan peraduan mengarang, dan hadiah sastera, dan sebagainya. Kajian ini keseluruhannya bertumpukan kepada 30 buah novel remaja Malaysia, tetapi hanya 5 buah yang dipilih mewakili setiap dekad. Kajian ini telah membuka mata pihak yang beranggapan bahawa novel remaja sebagai novel yang tidak memberikan manfaat kepada khalayak pembaca.

Seterusnya, pengkaji meneliti pula kajian Nurhamizah Hashim (2015) menerusi kajiannya yang bertajuk Psikologi Keperluan Remaja dalam Novel-Novel Remaja Hadiah Sastera Kumpulan Utusan (HSKU). Kajian ini bertujuan untuk menganalisis enam buah novel remaja Hadiah Sastera Kumpulan Utusan (HSKU), karya enam orang pengarang dengan menggunakan Pendekatan Hierarki Keperluan Remaja yang telah diubah suai dari Teori Hierarki keperluan Manusia. Novel-novel tersebut ialah Azfa Hanani (1995), Trilogi Cinta (2002) Merenang Gelora (2002), Merdekakan Cinta Ratna (2003), Beraraklah Awan Pilu (2006) dan Jendela Menghadap Jalan (2009). Oleh itu, objektif kajian ini adalah untuk mengenal pasti keperluan watak remaja, menganalisis keperluan watak remaja berdasarkan aplikasi Pendekatan Hierarki Keperluan Remaja serta merumuskan keperluan watak remaja yang dominan dalam setiap peringkat hierarki dari enam buah novel remaja tersebut. Analisis tersebut menggunakan lima peringkat utama yang terdapat dalam Pendekatan Hierarki Keperluan Remaja, iaitu keperluan fisiologi, keperluan keselamatan, keperluan kasih sayang dan cinta, keperluan penghargaan kendiri dan keperluan penyempurnaan kendiri. Permasalahan kajian yang bertolak daripada tempoh dan usia remaja akan wujud pelbagai keperluan, keinginan dan kehendak yang diperlukan oleh golongan ini bagi memenuhi impian, matlamat, visi dan misi yang dicita-citakan oleh mereka. Namun begitu, masih ada yang tidak memahami keperluan yang diperlukan oleh golongan remaja dan anak-anak mereka. Sering kali kemampuan, kebolehan, keperluan, kehendak dan keinginan mereka ini dianggap tidak universal kerana kehidupan mereka masih di bawah jagaan ibu dan bapa. Justeru, perlulah dilakukan satu kajian bagi melihat keperluan, keinginan dan kehendak-kehendak watak remaja yang timbul akibat daripada kekurangan keperluan atau berlakunya situasi keperluan yang tidak dipenuhi serta tindakan mereka bagi memenuhi kehendak tersebut dalam karya-karya yang telah dipilih. Kesimpulannya, watak remaja yang terdapat di dalam novel adalah merupakan cerminan remaja di alam realiti, maka boleh dikatakan bahawa keperluan, keinginan dan kehendak watak remaja yang ditonjolkan oleh pengarang dalam novel mereka adalah berdasarkan kehidupan remaja yang sebenar.

Selain itu, Faziela Abu Bakar @ Che Din dan Nik Rafidah Nik Muhamad Affendi (2016) dalam kajian Unsur Konflik dalam Novel Remaja Terpilih membicarakan tentang konflik remaja dalam novel-novel remaja terpilih. Novel remaja ini telah mencetuskan pendapat dan kritikan dari golongan penggiat sastera, badan bukan kerajaan (NGO), ahli akademik dan ramai lagi. Objektif kajian ini adalah untuk mengklasifikasikan dan menganalisis unsur konflik yang terdapat dalam novel yang dikaji. Dalam konteks kehidupan, manusia tidak pernah terlepas daripada menghadapi masalah hidup dan membuat kesilapan. Begitu juga 
permasalahan dalam kalangan remaja, yang seringkali dikaitkan dengan sifat remaja yang beremosi sehingga mencetuskan konflik. Hal ini kerana golongan remaja sangat mudah tersentuh dan beremosi sekiranya tersalah didik. Sehubungan dengan itu, kajian ini melihat aspek konflik daripada perspektif teori Humanistik Abraham Maslow. Hasil kajian mendapati teks ini menyentuh tentang aspek konflik seperti konflik dalam keluarga, konflik dalam diri dan konflik rakan sebaya yang terdapat dalam novel remaja pilihan. Setelah diteliti, konflik yang berlaku kepada watak mampu ditangani oleh remaja yang berkonflik. Kesemua watak berjaya dalam kehidupan setelah menghadapi pelbagai konflik. Pengalaman mematangkan diri dan menjadikan diri lebih yakin untuk menghadapi rintangan dan cabaran.

Selain itu juga, Kamariah Kamarudin (2017) dalam kajian yang bertajuk Mau'izah Remaja dalam Novel Satu Bulan Tiga Bintang Karya Ummu Hani Abu Hassan telah meneliti tentang usaha yang dijalankan untuk membentuk keperibadian anak muda. Konsep mau'izah yang digambarkan dalam Islam ini merupakan tunjang dalam pendidikan khususnya bagi membentuk sahsiah diri golongan remaja kepada nilai-nilai murni. Mau'izah bukan sahaja berguna dalam pembinaan jiwa anak muda bahkan dalam proses menghidangkan bahan bacaan yang bermanfaat dan memberi pengajaran kepada masyarakat amnya. Novel remaja merupakan bahan bacaan yang mampu meningkatkan sahsiah dan membentuk perilaku remaja. Kajian ini merungkai mau'izah remaja dalam novel bagi memperlihatkan sejauh mana usaha menasihati dan berpesan kepada kebaikan dan kebenaran ditampilkan pengarang kepada pembaca. Kehidupan ini akan terasa sunyi tanpa ada nasihat dan pengajaran.

Selanjutnya, Siti Khariah Mohd Zubir dan Nur Denna Samsudin (2016) bertajuk Analisis Watak dan Perwatakan dalam Novel Sejambak Bakti karya Rejab Fl. Novel ini merupakan novel komponen sastera (KOMSAS) dalam mata pelajaran Bahasa Melayu bagi tingkatan 1 Zon Sabah, Sarawak, Wilayah Persekutuan Labuan dan Johor. Objektif kajian dijalankan adalah untuk mengenal pasti watak dan perwatakan dalam novel Sejambak Bakti. Objektif yang kedua untuk menjelaskan watak dan perwatakan dan objektif yang ketiga ialah menganalisis novel menggunakan teori Psikoanalisis Sigmund Freud. Implikasi kajian ini terbahagi kepada tiga, iaitu kepada individu, pelajar dan masyarakat. Watak-watak novel ini juga banyak menggambarkan unsur-unsur positif seperti kerajinan, bekerjasama, semangat setia kawan, keazaman, dan sebagainya dalam melahirkan modal insan yang cemerlang. Dapatan kajian ini telah membuktikan bahawa watak-watak yang ditonjolkan juga tidak begitu kompleks dan mudah untuk difahami oleh para pelajar.

Tambahan pula, Rosnani Md Zain dan Nik Rafidah Nik Muhamad Affendi (2019) menerusi kajian yang bertajuk Unsur Sains dan Sastera dalam novel remaja terpilih meneliti unsur sains dan sastera yang terdapat dalam novel remaja terpilih. Kajian ini tercetus hasil pandangan sarjana sastera yang mengatakan novel-novel remaja sains dianggap tidak mengetengahkan fakta sains dan mengabaikan nilai sastera. Dalam kajian ini, kaedah yang digunakan ialah kaedah kualitatif, iaitu melalui kaedah kepustakaan, analisis teks dan penerapan teori Sistem Pemikiran Bersepadu (SPB4K). Pengkaji ingin merungkaikan kebenaran tentang unsur sains dan sastera dalam novel Tawanan Komander Caucausus (2010) karya Ruzaini Yahya dan Di Sebalik Dinara (2012) karya Dayang Noor. Justeru, dapatan kajian ini membuktikan bahawa novel-novel yang dibataskan terkandung unsur sains dan sastera yang dapat dicetuskan agar karya lebih dinamik. 
Kesimpulannya, kajian-kajian lepas memperlihatkan bahawa bidang kesusasteraan kian mendapat tempat dalam kalangan pengkaji-pengkaji. Dengan itu, tidak hairanlah jika para sarjana giat menjalankan kajian tentang novel bagi memartabatkan bidang kesusasteraan Melayu pada masa kini. Namun begitu, masih terdapat kelompongan kajian daripada aspek kemasyarakatan dalam novel. Hal ini kerana kajian-kajian lepas memperlihatkan gaya penulisan novel, perwatakan dan jalan penceritaan berbanding aspek kemasyarakatan dalam novel. Oleh itu, kajian ini berupaya untuk mengisi kelompongan tersebut dengan menerajui aspek kemasyarakatan dalam hasil karya A. Samad Said. Kesannya, aspek kemasyarakatan dalam novel Melayu mampu diserap ke dalam jiwa para pembaca selain mampu memartabatkan hasil kesusasteraan Melayu

\subsection{Penyataan Masalah Kajian}

Pengkaji telah mengenal pasti kelompongan kajian melalui pemerhatian yang telah dilaksanakan terhadap sorotan kajian lepas. Terdapat beberapa kajian mengenai novel yang dilaksanakan oleh para sarjana. Hal ini merujuk kepada kajian-kajian lepas tentang novel termasuklah Dinamika Tema dalam Novel Remaja di Malaysia meneliti dinamika tema dalam novel remaja di Malaysia, bermula dari tahun 1950-an hingga tahun 2000-an oleh Halis Azhan Mohd.Hanafiah (2014), Psikologi Keperluan Remaja dalam Novel-Novel Remaja Hadiah Sastera Kumpulan Utusan (HSKU) oleh Nurhamizah Hashim (2015), Unsur Konflik dalam Novel Remaja Terpilih membicarakan tentang konflik remaja dalam novelnovel remaja terpilih oleh Faziela Abu Bakar @ Che Din dan Nik Rafidah Nik Muhamad Affendi (2016), Mau'izah Remaja dalam Novel Satu Bulan Tiga Bintang Karya Ummu Hani Abu Hassan oleh Kamariah Kamarudin (2017), Analisis Watak dan Perwatakan dalam Novel Sejambak Bakti karya Rejab Fl oleh Siti Khariah Mohd Zubir dan Nur Denna Samsudin (2016), serta Unsur Sains dan Sastera dalam novel remaja terpilih meneliti unsur sains dan sastera yang terdapat dalam novel remaja terpilih oleh Rosnani Md Zain dan Nik Rafidah Nik Muhamad Affendi (2019). Hasil daripada pengamatan pengkaji mendapati terdapat kelompongan terhadap kajian-kajian lepas oleh para sarjana sastera. Kajian-kajian lepas kebanyakannya menekankan aspek remaja berbanding dengan kemasyarakatan. Oleh itu, kajian ini adalah bertujuan untuk menumpukan terhadap aspek kemasyarakatan melalui pemikiran A. Samad Said dalam novel popular beliau.

Selain itu juga, kajian ini mendapati tiada penyelidikan khusus terhadap aspek kemasyarakatan di dalam novel. Hal ini kerana kajian-kajian lepas hanya memberi fokus terhadap golongan muda khususnya remaja dalam kehidupan seharian. Kajian-kajian lepas dilihat menekankan konflik yang dihadapi oleh golongan muda berbanding aspek kemasyarakatan. Kesannya, konflik yang dihadapi dalam kalangan masyarakat kurang diketengahkan oleh pengkaji-pengkaji sebelum ini. Aspek kemasyarakatan dalam novel kurang diketahui oleh pembaca-pembaca kerana pengkaji lebih ke arah permasalahan yang dihadapi oleh remaja. Penelitian secara khusus terhadap aspek kemasyarakatan perlu dilakukan bagi membuka mata masyarakat mengenai konflik yang berlaku terutama dalam aspek agama, sosial dan ekonomi. Hal ini dikatakan demikian kerana, aspek kemasyarakan juga merupakan isu yang serius sewajarnya dibincangkan agar membuahkan fikiran dan jalan penyelesaian terhadap isu yang berlaku dalam aspek kemasyarakatan. Oleh itu, kajian ini akan menumpukan terhadap aspek kemasyarakatan melalui pemikiran A. Samad Said dalam novel popular beliau. 


\subsection{Metodologi Kajian}

Kajian ini bersifat kualitatif yang melibatkan kaedah kepustakaan dan teks. Kaedah kepustakaan merujuk kepada proses pengumpulan data mengenai kajian untuk mendapatkan data dan maklumat sedia ada yang sesuai dengan kajian. Sebagai contohnya artikel, jurnal, tesis, buku dan kertas kerja yang berkaitan novel dan juga teori sosiologi. Kaedah ini tertumpu di perpustakaan terpilih seperti Perpustakaan Univsiti Malaysia Kelantan, Perpustakaan Universiti Kebangsaan Malaysia, Perpustakaan Universiti Putra Malaysia dan Perpustakaan Universiti Malaya. Selain itu, kaedah analisis kandungan teks pula melibatkan pembacaan novel Daerah Zeni dan Hujan Pagi oleh A. Samad Said. Novel Daerah Zeni diterbitkan pada tahun 1985 dan Hujan pagi pada tahun 1992. Setelah itu, novel-novel tersebut dianalisis secara sistematik bagi menemukan aspek kemasyarakatan dan seterusnya diaplikasikan menggunakan teori sosiologi yang dipelopori oleh Laurenson dan Swingewoods (1972).

\subsection{Teori Sosiologi}

Menurut Laurenson dan Swingewoods (1972) menjelaskan bahawa pengkajian sosiologi yang berfokus kepada aspek masyarakat dan kemasyarakatan merupakan satu bidang ilmu yang memberi tumpuan terhadap individu dan masyarakat secara saintifik dan objektif. Selain itu, kajian sosiologi merangkumi kajian tentang kedudukan individu dalam masyarakat, kajian mengenai institusi sosial, proses bersosialisasi serta sejarah masyarakat itu. Berkaitan dengan pertalian antara masyarakat dengan persekitaran sewaktu berkarya. Dalam hal ini, hubungan masyarakat dan persekitaran sangat rapat dan saling melengkapi untuk memahami isu-isu masyarakat dan sejarah.

Laurenson dan Swingewoods (1972) memperincikan pendekatan sosiologi dengan melihat tiga dimensi seperti yang ditunjukkan dalam Rajah 1. Pertama, melihat karya sastera sebagai dokumen sosiobudaya yang mencerminkan satu zaman. Hal ini terjadi demikian kerana setiap hasil karya yang dikarang akan ditapis dan dinilai sendiri oleh pujangga sastera. Hal ini menyebabkan pujangga sastera mampu memahami alam dan persekitaran yang dialami oleh masyarakat setempat. Kesannya, hasil karya lebih bersifat kreatif dan inovatif kerana dirangsang oleh persekitaran yang berlaku dalam masyarakat setempat.

Dimensi seterusnya ialah melihat dari segi penghasilan karya sastera terutama yang berhubungan dengan kedudukan sosial seorang penulis. Seterusnya, setelah seorang penulis mendapat perhatian hasil daripada penulisannya, maka hasil karya seterusnya akan memberi impak kepada kehidupan masyarakat. Hal ini disebabkan oleh pengaruh kedudukannya sebagai penulis mampu memberi peringatan, nasihat dan panduan dalam menyampaikan mesej kepada masyarakat. Hal ini mengakibatkan masyarakat setempat lebih menghormati kesantunan bahasa serta peka akan isu-isu sensitiviti yang dihadapi oleh mereka. Natijahnya, hasil karya sastera mampu mengubah aspek sosial, budaya dan Pendidikan antara penulis dan masyarakat setempat.

Selain itu, dimensi ketiga merujuk kepada penerimaan suatu masyarakat terhadap 
karya daripada seseorang penulis tertentu. Hal ini wujud akibat daripada perspektif masyarakat yang menekankan adat istiadat dan kepercayaan nenek moyang berbanding kehidupan berteraskan modenisasi. Oleh itu, hasil karya sastera mulai menerapkan nilai-nilai murni dan institusi sosial yang bersesuaian dengan masyarakat. Akibatnya, hasil karya yang dihasilkan oleh penulis akan memenuhi aspek sosial, ekonomi dan politik masyarakat setempat dan diterima secara baik oleh setiap komunitinya. Pendekatan sosiologi sastera dijadikan landasan pengkajian disebabkan wujudnya hubungan yang erat antara sastera dengan masyarakat. .

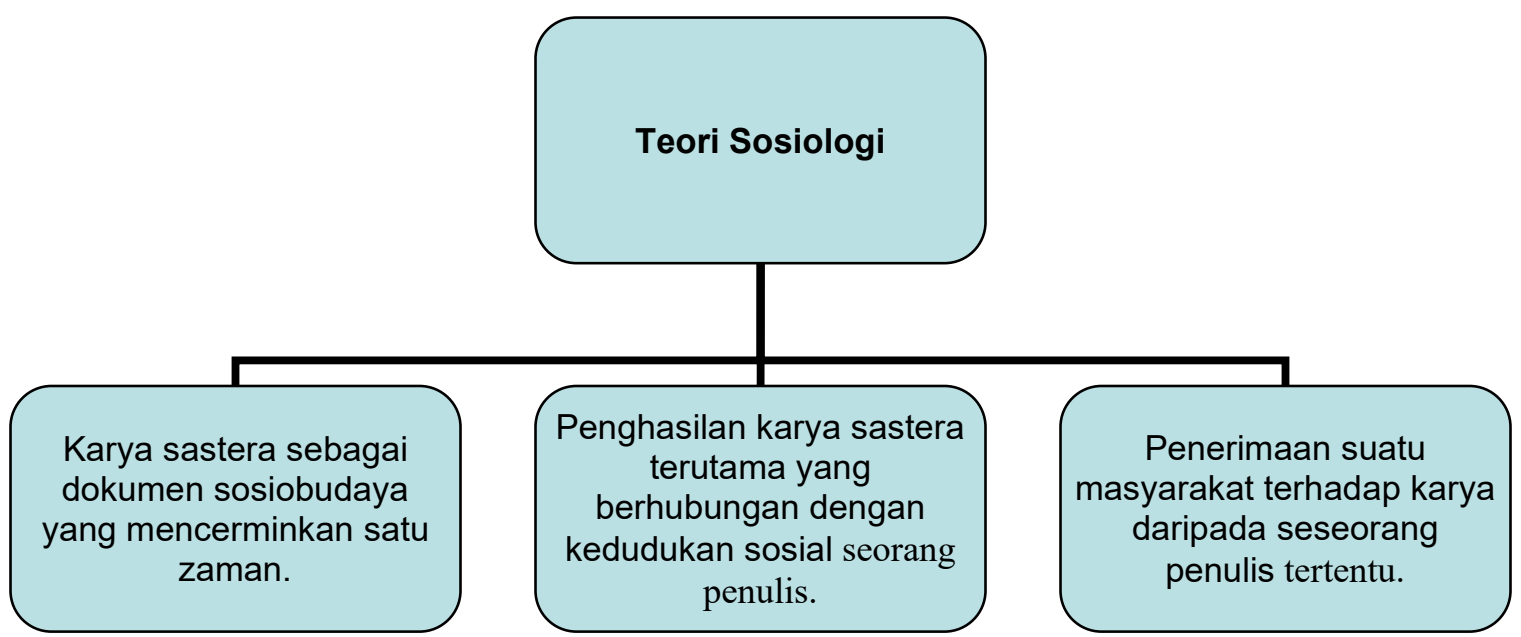

Rajah 1: Kerangka Teori Sosiologi oleh Laurenson dan Swingewoods (1972)

\subsection{Analisis dan Dapatan Kajian}

Pada bahagian ini, pengkaji menganalisis pemikiran pengarang oleh penulis muda dalam konteks masyarakat seperti aspek agama, sosial dan ekonomi secara terperinci.

\subsection{Aspek Agama}

Menurut H. Ibrahim Lubis (1982), agama merupakan sebuah peraturan yang membawa manusia ke arah ketenangan zahir dan batin. Selain itu, menurut Sayyid Qutb (1983), agama merupakan sumber yang mengandungi sistem hidup yang sesuai dengan fitrah kemanusiaan yang dapat direalisasikan dalam semua aspek kehidupan. Di samping itu, agama adalah sebagai sebuah panduan yang merangkumi pegangan hidup, ibadah, amalan, pertimbangan dan akhlak mulia seseorang manusia dalam kehidupan (Zulkiple Abd Ghani dan Nor Salimah Abu Mansor 2006). Berdasarkan pendapat para tokoh, dapat disimpulkan bahawa agama merupakan sebuah panduan hidup kepada manusia untuk menjalani kehidupan yang lebih baik dan tidak terpesong daripada ajaran agama.

Menerusi novel Hujan Pagi pengarang mengutarakan tentang perkara yang 
melibatkan agama dan masyarakat. Doa merupakan pengakuan manusia tentang kelemahannya, namun manusia kadangkala bersikap sombong (QS. 96:6-7). Doa juga sering dilupakan manusia, karena manusia masih banyak yang menganggap bahawa doa itu kurang penting, sehingga manusia tidak mengakui keberadaan doa tersebut. Padahal, manusia yang hidup tanpa gejolak, tanpa kekuasaan istimewa, bekerja dan berjuang secara wajar untuk memenuhi kebutuhan sehari-hari, juga memerlukan doa sebagai motivasi dirinya agar dapat melanjutkan usaha untuk mencapai cita-citanya. Doa juga menjadi salah satu sebab tertolaknya suatu bencana Di samping itu doa merupakan ubat penawar yang paling mujarab, sehingga menjadi musuh bagi bala (petaka). Doa dapat menolaknya, menghilangkannya, menyembuhkannya, atau meringankannya. Menerusi novel Hujan Pagi dapat dilihat melalui watak Gazis yang berpegang teguh kepada agama Islam. Hal ini jelas dapat dilihat apabila adiknya Jirim dirasuk oleh Jin. Setelah adiknya dirasuk, Gazis meminta pertolongan dengan memohon doa daripada Allah S.W.T. Contohnya dapat dilihat dalam petikan di bawah:

Petikan 1

Melalui matanya saja Gazis tahu Lokman banyak bertanya. Mereka bersamasama mengangkat Jirim, membaringkannya di atas ambing. Gazis berdiri menggeleng-geleng menyaksikan keadaan Jirim. Sementara Lokman pergi mengambil air dan tuala, Gazis mula membacakan beberapa potong ayat suci ke muka adiknya. Dia benar-benar meminta melalui doanya."

(A. Samad Said, 1992)

Menerusi petikan di atas, pengarang menggambarkan tentang kepentingan doa dalam kehidupan manusia. Doa merupakan suatu amalan yang perlu diamalkan selalu untuk meminta pertolongan daripada Allah S.W.T untuk meminta pertolongan dari-Nya. Pengarang menggambarkan watak Gazis yang meminta pertolongan daripada Allah S.W.T dengan membaca sepotong doa setelah adiknya dirasuk oleh jin. Hal ini kerana, Gazis percaya bahawa doa yang dibaca boleh menyembuhkan adiknya yang tidak sedarkan diri kerana dirasuk oleh jin. Dalam konteks ini, maka jelas membuktikan bahawa doa merupakan suatu amalan yang penting dalam kehidupan kita sebagai manusia untuk menjadikan doa tersebut sebagai amalan harian bagi meminta pertolongan daripada Tuhan sekiranya terdapat ujian atau musibah dalam hidup.

Menerusi pendekatan sosiologi yang berlandaskan masyarakat dan kemasyarakatan, menurut Laurenson dan Swingewoods (1972) menjelaskan bahawa pengkajian sosiologi yang berfokus kepada aspek masyarakat dan kemasyarakatan merupakan satu bidang ilmu yang memberi tumpuan terhadap individu dan masyarakat secara saintifik dan objektif. Doa adalah penghubung manusia dengan pencipta-Nya. Bagi umat Islam, doa amat digalakkan untuk meminta bantuan, perlindungan, dan keselamatan serta kesejahteraan. Doa dilakukan tanpa mengira tempat dan suasana. Sementara itu, doa dipinta sama ada secara dilafazkan atau sebaliknya.

Menerusi novel Daerah Zeni aspek agama yang di bincangkan oleh pengarang 
ialah kecintaan ilmu agama. Kecintaan kepada ilmu agama itu menggambarkan setiap manusia bersungguh-sungguh menuntut segala ilmu dunia dan ilmu akhirat dengan niat ikhlas kerana Allah. Mereka mengejar ilmu agama kerana Allah serta yakin bahawa setiap ilmu yang dipelajari boleh memberi suatu cahaya hidup dalam menyinari sebuah kehidupan setiap manusia yang bersungguh-sungguh menuntut ilmu tersebut. Islam menuntut umatnya supaya mencari dan mencintai ilmu kerana dengan menuntut ilmu pengetahuan itu dapat mengubah manusia menjadi lebih baik, berakhlak mulia dan bertamadun. Seseorang yang berilmu dapat membezakan antara perkara yang baik dengan yang buruk. Menuntut dan mencintai ilmu bukan sahaja ilmu agama tetapi ilmu-ilmu keduniaan juga perlu dicari agar seseorang umat itu mampu hidup bahagia di dunia dan di akhirat. Hal ini dapat dilihat dalam petikan:

Petikan 2

"Semakin hari dia semakin senang, khususnya kerana Zirah seorang pendamping agama, sering pinta dihantar ke kelas atau ke ceramah agama. Memang Zirah lebih tahu tentang agama. Malah boleh diperkatakan hampir seluruh buku agama di kutubkhanah itu sudah dibacanya. Zedi pernah menyarankan kepada pengetua institusi tersebut supaya mengusahakan lebih banyak lagi buku agama, tapi, jawab pengetua, banyak surat rayuan buku yang dihantarnya tidak dilayani."

(A Samad Said, 1992)

Berdasarkan petikan di atas jelas menunjukkan seorang watak yang bernama Zirah amat takut dalam mendapatkan ilmu. Zirah dikatakan sering membaca buku-buku agama dan juga sering meminta untuk menghadiri ceramah-ceramah agama. Menerusi gambaran cerita tersebut, pengarang menggambarkan tentang pentingnya ilmu agama untuk kehidupan manusia di dunia dan di akhirat. Hal ini kerana setiap manusia wajar melengkapkan diri mereka dengan ilmu agama. Seperti mana setiap manusia itu perlu membaca al-quran sebagai pegangan hidup dan sebagainya untuk menjadikan hidup seseorang itu lebih bahagia dan sejahtera atas keberkatan daripada Allah S.W.T. Dalam konteks ini, ilmu agama itu sangat penting dalam sesebuah kehidupan manusia kerana kecintaan manusia kepada ilmu agama wajar diasuh dan disemai dalam diri mereka agar kehidupan seseorang itu diberkati dan dirahmati oleh Allah S.W.T. di dunia dan di akhirat yang sedang menanti.

Menerusi pendekatan sosiologi yang berlandaskan masyarakat dan kemasyarakatan turut bertunjangkan kepada ilmu pengetahuan dapat diperoleh daripada pembelajaran yang dicari dan dituntut. Dengan memiliki ilmu seseorang itu mampu mengubah pendirian, sikap, dan matlamat yang didukung dalam kehidupannya. Mencintai ilmu agama merupakan perkara mulia yang perlu dilakukan oleh setiap insan. IImu agama membolehkan seseorang itu terhindar dari melakukan perkara yang dilarang dalam agamanya. Pelbagai cara yang dapat dilakukan dalam menuntut ilmu agama seperti pergi ke kuliah atau ceramah agama dan membaca berkaitan agama. Dalam konteks ini, permasalahan tersebut berkaitan dengan masalah masyarakat dan kemasyarakatan serta pendekatan teori 
sosiologi ini sangat bertepatan digunakan untuk mengaplikasikan isu tersebut.

Seterusnya dalam novel Hujan Pagi, pengarang menggambarkan terhadap pegangan akidah kepada manusia yang beragama Islam. Menerusi novel Hujan Pagi dapat dilihat watak Lokman yang terpesong akidah. Dia terpengaruh dengan dunia khayalan sendiri sehingga sanggup menidakan kuasa Tuhan lantaran daripada meminta pertolongan makhluk halus untuk menjayakan akhbar yang dicipta dalam dunianya sendiri. Contohnya menerusi petikan di bawah:

Petikan 3

Tiba-tiba kelihatan tangannya terketar, mukanya sedikit merah, dan tiba-tiba juga suaranya berubah, dia hampir menderam: "Hai sahabat Mamang Tali Harus, yang berulang ke pusat Tasik Pauh Janggi, sampaikan pesanku ini, kepada Datuk Si Rimbun Alam: Aku minta tolong pelihara kawan-kawanku," dia terhenti. Matanya yang separuh merah dan separuh rahsia merenung Lajis, mengalah. "Maafkan, bukan aku yang serapah itu. Itulah... itulah yang disebut atau dijeritkan oleh Lokman pada waktu-waktu tertentu. Kau tahu serapah itu? Mantera...ya, mantera hati laut! Kau tahu?"

(A. Samad Said, 1992)

Menerusi petikan tersebut, pengarang menggambarkan individu yang terpesong akidah dalam dirinya kerana tersasar jauh daripada ajaran Islam. Hal ini kerana, Lokman yang menggunakan kuasa ghaib untuk memajukan perniagaan yang dijalankan. Dia percaya akan kuasa ghaib itu boleh membantu untuk kemajuan dan kejayaan dalam perniagaan tersebut. Dalam konteks ini, membuktikan Lokman rosak akidah kerana dia lebih percaya kepada kuasa ghaib berbanding kuasa Tuhan dalam meminta pertolongan tersebut.

Akidah merupakan pegangan yang wujud dalam diri setiap umat yang beragama Islam. Oleh hal yang demikian, akidah juga adalah penentu kepada perbuatan, tingkah laku, dan tindak tanduk dalam diri seseorang manusia. Akidah dalaman yang baik memberikan perspektif luaran yang sempurna kepada sesiapa sahaja yang melihatnya, manakala akidah yang tidak elok dalam diri seseorang akan dipandang serong oleh masyarakat. Jelaslah di sini, akidah merupakan asas kepada pembentukan ummah khususnya ummah Islam di seluruh pelosok dunia dan manusia yang berpegang teguh kepada akidah Islam nescaya mereka akan memperoleh kebahagiaan dan kejayaan di dunia dan di akhirat. Dalam konteks ini, akidah juga merupakan medium yang berkait rapat dengan masyarakat dan kemasyarakatan dalam sesebuah kehidupan manusia sejagat. Oleh hal yang demikian, menerusi pendekatan sosiologi tersebut, maka terbuktilah bahawa akidah merupakan wahana yang berlandaskan kepada masyarakat dan kemasyarakatan.

Seterusnya, menerusi novel Daerah Zeni memperlihatkan keimanan kepada Allah S.W.T. untuk membuktikan ketakwaan umat manusia kepadanya. Manusia dijadikan oleh Allah sebaik-baik umat di muka bumi yang penuh dengan pancaroba ini. Dalam agama Islam, umat manusia dituntut untuk beriman kepada Allah. Hal ini kerana, manusia dijadikan sebagai khalifah yang sempurna akal dan sifatnya 
supaya boleh beriman kepada Allah dengan penuh tawaduk. Oleh hal yang demikian, beriman kepada Allah SWT merupakan perkara yang wajib kepada semua umat Islam. Seseorang yang beriman hanya melakukan perkara yang suruh sahaja dan tidak akan melakukan sesuatu yang sudah dilarang di dalam agama. Sehubungan dengan itu, Islam melarang umatnya berbuat jahat sesama manusia bahkan mengutuk hambanya yang melakukan sirik kepada Allah SWT. Hal ini dapat dijelaskan dalam petikan:

Petikan 4

"aku tak gunakan tuju-tuju, aku tak gunakan santau untuk bunuh Kordi. Itu fitnah, tohmah. Aku tak bunuh Kordi pun seperti yang disangka Kinah tu," Raja Debet terdengar penafian Dol Zaleh kepada Mardi. "Orang yang beriman, yang bertakwa kepada Allah, tak guna tuju-tuju, tak guna santau..." Dol Zaleh terhenti. "itu bukan kerja orang Islam."

(A. Samad Said, 1992)

Berdasarkan petikan di atas menunjukkan seorang watak bernama Dol Zaleh menafikan tuduhan yang dilemparkan kepadanya yang mengatakan dia menggunakan santau untuk membunuh orang lain. Beliau menyatakan seseorang yang beriman tidak akan melakukan perkara yang dianggap terpesong dari landasan agama. Oleh hal demikian, insan yang berpegang teguh kepada agama Allah tidak mudah alpha dan jauh di sisi Allah kerana mereka sentiasa mendekatkan diri kepada Allah. Manusia yang beriman tidak sesekali menyekutukan Allah serta percaya kepada perkara syirik kerana ketakwaan dalam diri mereka sangat utuh. Dalam konteks ini, manusia wajar beriman kepada Allah kerana mereka mampu menjadi hamba yang taat dan patuh kepada setiap syariat yang ditetapkan dalam agama Islam dan tidak mungkin akan mudah terpesong akidahnya serta sentiasa mendapat keredaan daripada Allah yang Esa.

Agama Islam merupakan pegangan yang utuh di dalam kehidupan masyarakat Melayu dan telah dianutinya sejak sekian lama. Masyarakat Melayu yang berpegang teguh dengan agama Islam akan meninggalkan segala larangan dan tegahan yang telah digariskan di dalam agama Islam. Agama Islam mengajar umatnya untuk melakukan kebaikan kepada semua antara makhluk dengan makhluk serta dengan alam sekalipun agama Islam menuntut Umatnya melakukan kebaikan. Perbuatan keji seperti melakukan sihir atau santau kepada orang lain merupakan perbuatan terkutuk yang telah wujud dalam masyarakat Melayu pada masa kini mahupun ketika dahulu. Perbuatan ini akan mengundang kemurkaan Allah SWT dan akan mendapat balasan yang setimpal di akhirat. Dalam konteks ini, pendekatan teori sosiologi sangat bertepatan digunakan untuk mengaplikasikan permasalahan yang dibicarakan menerusi gambaran cerita tersebut.

\subsection{Aspek sosial}

Sosial adalah sebuah sistem kehidupan bersama dalam masyarakat yang mencakupi struktur, organisasi, nilai-nilai sosial dan aspirasi hidup dan cara mencapainya (Ranjabar, 2006). Menurut Enda (2010), sosial merupakan cara atau 
kaedah yang digunakan oleh setiap individu untuk berhubung dengan individu lain dalam sesebuah masyarakat. Seterusnya, sosial dapat didefinisikan sebagai sebuah perkara yang wujud secara bersama untuk mempertingkatkan daya kemajuan dalam sesebuah masyarakat (Dani Manesah, 2017). Sebagai rumusannya, sosial merupakan satu aspek yang memainkan peranan penting dalam menentukan kesejahteraan sesebuah masyarakat dan seharusnya dijaga supaya tidak runtuh serta sentiasa menjadi penguat dalam sesebuah organisasi masyatakat.

Menerusi perbincangan tentang aspek sosial kajian ini hanya menyentuh tentang masalah sosial seperti menuntut ilmu pengetahuan dalam novel Hujan Pagi, manakala menerusi novel Daerah Zeni aspek sosial yang dibincangkan tentang penceraian. Oleh hal yang demikian, menerusi novel Hujan Pagi pengarang menggambarkan tentang pentingnya seseorang manusia untuk menuntut ilmu bagi mencapai kejayaan dalam hidup mereka. Walaupun ilmu manusia bagai setitis air di lautan tetapi mampu membuka rahsia alam semesta ini. maka siapa saja yang berilmu Allah akan meninggikan darjatnya satu tingkat dari yang tidak berilmu. jadi ilmu adalah kemampuan manusia untuk membaca apa yang ada di jagat dan dituangkan dalam bentuk karya, rasa, cipta dan mampu mengubah sesuatu keadaan secara bersistem dan berstruktur dalam kurun waktu yang lama. Menerusi dalam novel Hujan Pagi dapat dilihat berdasarkan watak Gazis yang mementingkan ilmu pengetahuan dalam dirinya semasa melakukan pekerjaan. Contohnya boleh dilihat berdasarkan petikan di bawah:

\section{Petikan 5}

"Saya belajar dari belakang kotak huruf itu sendiri. Meneliti setiap huruf rencana, berita atau ulasan daripada orang-orang bijak seperti awak semua," kata Gajis. Sudah cukup sejauh itu."

"Awak sendiri yang tak sedia mahu mengakui atau memberi peluang kepada diri mu. Percayalah, tempat awak memang bukan di hadapan kotak huruf itu. Awak sepatutnya menjadi..."

"Wartawan besar!" kata Gazis sedikit terbahak.

(A. Samad Said, 1992)

Menerusi petikan tersebut, pengarang menjelaskan tentang pentingnya ilmu pengetahuan kepada seseorang itu. Boleh dilihat berdasarkan watak Gazis yang sentiasa belajar daripada awal dalam setiap pekerjaan yang dilakukan. Dia sentiasa memerhati setiap kerja yang dilakukan oleh pekerja-pekerja di tempat dia bekerja. Di samping itu, Gazis selalu mempraktikkan setiap kerja-kerja tersebut dengan bersungguh-sungguh untuk mendapat suatu hasil yang baik. Dalam konteks ini, pengarang menjelaskan betapa pentingnya ilmu pengetahuan kepada seseorang demi memajukan diri mereka dalam melakukan setiap perkara yang diperoleh.

IImu pengetahuan merupakan salah satu elemen penting dalam kehidupan manusia. IImu umpama lilin yang menyinari kegelapan manusia. Tamnpa ilmu manusia akan sesat dalam menempuhi liku-liku kehidupan yang penuh onak dan duri. Dalam konsep ajaran agama Islam, umat Islam digalakkan menuntut ilmu 
sehingga ke liang lahat. Manakala dalam pepatah Melayu berbunyi tuntutlah ilmu hingga ke negeri China. Hal ini dapat disimpulkan melalui pepatah di atas, ilmu memainkan peranan penting dalam diri seseorang bagi mencapai apa yang diimpikan dalam hidup. Jelaslah di sini, kewajipan menuntut ilmu oleh. setiap manusia akan membawa masyarakat yang cemerlang, gemilang dan terbilang. Melalui perasaan cintakan ilmu yang disemai akan mendatangkan kejayaan dalam hidup dan kemajuan negara. Tidak mustahillah negara akan dipandang tinggi oleh negara lain. Oleh hal yang demikian, menerusi pendekatan sosiologi tersebut, maka terbuktilah bahawa ilmu pengetahuan merupakan medium yang berlandaskan kepada masyarakat dan kemasyarakatan.

Selanjutnya, menerusi novel Daerah Zeni aspek sosial yang dibincangkan ialah isu penceraian. Pemikiran sosial seterusnya berkaitan dengan isu perceraian yang dapat difahami penceraian merupakan perpisahan yang berlaku antara dua insan bergelar suami dan isteri. Masalah perceraian ini berlaku apabila sebuah institusi rumah tangga yang terbina tidak lagi mampu dipertahankan. Suami dan isteri yang memilih untuk hidup berasingan dan tidak lagi sebagai pasangan dan ini merupakan jalan terakhir di dalam sesebuah perhubungan. Hal ini dapat dilihat di dalam petikan di bawah:

Petikan 6

"Kau yang kikis, kau yang putuskan. Kau lupa itu?" jawab Zeni, sengaja lebih kasar.

"Kau yang meminta. Pagi, petang, siang, malam kau yang minta. Lebih 44 kali kau minta. Makbul!!

"Aku senang makbul!"

"kau tahu, kau tak seperti kebanyakan wanita lain yang memuja rumah tangga..."

"rumah tangga yang bagaimana yang kau maksudkan?"

"pagi, petang, siang, malam, kau tak sedia terima penderitaan. Tak cekal, tak sungguh-sungguh!"

"rumah tangga bagaimana yang kau maksudkan, hah?" suara Zeni meninggi.

(A. Samad Said, 1985)

Berdasarkan petikan tersebut dapat dibuktikan berlakunya masalah sosial iaitu perceraian. Watak yang bernama Zeni telah meminta dia untuk diceraikan oleh suaminya yang bernama Mordi dan perkongsian hidup yang tidak mempunyai persefahaman akhirnya runtuh. Oleh hal yang demikian, pengarang jelas menggambarkan tentang masalah penceraian yang dihadapi oleh pasangan suami isteri yang berumah tangga. Pertelingkahan antara suami dan isteri dalam sesebuah keluarga sering berlaku dan jika tidak ditangani dengan sebaik mungkin ia pasti akan menyebabkan pergaduhan sehingga boleh menghuru-harakan rumah tangga yang dibina. Dalam konteks ini, penceraian boleh berlaku sekiranya keduadua belah pihak tidak boleh lagi berbincang dengan baik dan tidak sanggup hidup bersama atas sebab masing-masing tidak boleh mengalah dalam menyelesaikan suatu masalah rumah tangga yang dihadapi. 
Permasalahan yang melanda sesebuah institusi rumah tangga seperti penceraian sering kali menjadi masalah di dalam masyarakat pada masa kini. Perceraian akan berlaku apabila sesebuah pasangan itu tidak lagi mampu bertahan untuk hidup bersama disebabkan pasangannya atau kedua-duanya mempunyai pandangan yang tersendiri sehinggakan tidak dapat diterima oleh pihak lain. Masalah yang sering berlaku di dalam hubungan umumnya hubungan pasangan suami isteri apabila wujud ketidakpercayaan antara satu sama lain, ketidakjujuran, penindasan hak pasangan akan menjurus kepada masalah penceraian yang berlaku dalam masyarakat kini. Dalam konteks ini, permasalahan tersebut berkaitan dengan masalah masyarakat dan kemasyarakatan serta pendekatan teori sosiologi ini sangat bertepatan digunakan untuk mengaplikasikan isu tersebut.

\subsection{Aspek Ekonomi}

Menurut Akhmad Fauzi (2006), ekonomi merupakan salah satu komponen penting dalam sistem kehidupan manusia yang berperanan sebagai sumber yang menyediakan keperluan barangan dan kewangan kepada masyarakat. Selain itu, menurut Mit Witjaksono (2009), ekonomi adalah sebagai proses pembangunan sesebuah negara untuk memastikan kesejahteraan rakyat supaya sentiasa berada dalam keadaan yang stabil. Tambahan lagi, ekonomi adalah satu kegiatan untuk yang bertujuan untuk memenuhi keperluan hidup dan mempertingkatkan kualiti kehidupan serta kesejahteraan sesebuah masyarakat (Amiruddin Idris 2018). Sebagai rumusannya, aspek ekonomi memainkan peranan penting dalam memastikan kehidupan masyarakat terus berada dalam keadaan yang stabil dan mencukupi dari aspek kewangan dan keperluan harian.

Menerusi novel Hujan Pagi pengarang mencetuskan tentang perniagaan dalam bidang akhbar melalui aspek ekonomi secara khusus. Perniagaan wujud apabila manusia mengkhususkan dalam pengeluaran barangan dan perkhidmatan yang mereka berkemahiran dan cekap. Perniagaan banyak memberi faedah kepada manusia kerana aktiviti-aktiviti perniagaan dapat memenuhi kehendak dan keperluan manusia dengan menyediakan berbagai-bagai barangan dan perkhidmatan yang dikeluarkan sama ada di dalam negara ataupun diimport dari luar negara. Selain itu, perniagaan juga menjanakan keuntungan yang menggalakkan manusia berkecimpung dan mengembangkan perniagaan pulangan kepada pemilik-pemilik yang sanggup menghadapi risiko daripada pelaburan wang dan masa mereka. Perniagaan adalah pertukaran barang atau perkhidmatan dengan wang untuk tujuan mendapatkan keuntungan atau sebarang bentuk faedah. Perniagaan dalam bidang akhbar, ia melibatkan bahan-bahan penerbitan yang di cetak dalam apa-apa bahasa untuk dijual atau diedarkan dengan percuma secara berkala pada lat-lat tempoh tertentu tetapi tidak termaksud yang diterbitkan oleh atau untuk kerajaan persekutuan atau mana-mana kerajaan negeri atau kerajaan Singapura. Oleh itu, akhbar memainkan peranan penting dalam menyumbangkan sumber ekonomi kepada negara.

Berdasarkan dalam novel Hujan Pagi, dapat dilihat melalui watak Lokman yang menjadi seorang ketua pengarang hanya mendapat pendapatan melalui perniagaan akhbar. Mereka terpaksa menghadapi berbagai halangan dan rintangan dalam 
menghadapi penjajah. Lokman bercita-cita untuk memajukan masyarakat dengan menggunakan akhbar Hujan Pagi. Contohnya dapat dilihat dalam petikan di bawah:

Petikan 7

"Akhbar kita ini bukan saja terpaksa bersaing untuk hidup dari segi perniagaannya. Itu memang sudah lama kita lakukan. Akhbar kita juga terpaksa bertahan atau belajar bertahan daripada dihancurkan," kata Lokman. Terdengar keresahan serentak. Lokman cepat-cepat mengangkat kedua-dua belah tangannya. Dia berhenti lebih lama sedikit. "Sebenarnya sudah lebih dari lapan bulan akhbar mingguan kita ini diawasi." Terdengar keresahan serentak lagi.

(A. Samad Said, 1992)

Menerusi petikan tersebut, pengarang menggambarkan tentang pentingnya menjalankan perniagaan akhbar. Hal ini kerana dalam bidang perniagaan akhbar kita mesti merebut peluang yang datang kepada kita serta mesti bersaing dalam perniagaan yang diceburi. Dalam konteks ini, memandangkan bidang perniagaan akhbar itu penting dalam memajukan ekonomi sesebuah empayar perniagaan yang dijalankan, semua pihak perlu memainkan peranan yang penting dalam memajukan perniagaan yang dijalankan dan sentiasa mencari peluang yang datang untuk terus berjaya dalam perniagaan tersebut.

Perniagaan juga merupakan suatu bidang yang menyumbangkan hasil ekonomi kepada sesebuah negara. Oleh itu, perniagaan akhbar membuka ruang pekerjaan kepada masyarakat dalam mencetuskan gagasan idea untuk kesejahteraan masyarakat pada ketika itu. Dalam perspektif ekonomi, ia merupakan penanda aras dalam bidang penerbitan akhbar. Jelaslah perniagaan akhbar merupakan bidang penting untuk memajukan sektor ekonomi sesebuah negara. Lantaran itu, bidang akhbar juga bukan sekadar mengaut keuntungan semata-mata malah ia memberikan ilmu pengetahuan kepada masyarakat tanpa mengira peringkat umur. Dalam konteks ini, pendekatan sosiologi adalah sangat bersesuaian dikaitkan dengan isu perniagaan akhbar kerana ia berlandaskan kepada fenomena manusia itu secara sistematik dan melibatkan masyarakat dan kemasyarakatan secara tepat.

Menerusi novel Daerah Zeni pula aspek ekonomi yang dibincangkan ialah kepesatan pembangunan. Kepesatan merupakan kemajuan yang dicapai dengan cepat. Setiap perkara yang dilakukan oleh pemerintah dalam sesebuah negara itu seandainya lebih konsisten dan sistematik, maka percayalah kemajuan sesebuah negara itu boleh dicapai dengan mudah dan mendapat hasil yang membanggakan. Rakyat jelata akan merasa bangga atas kemajuan yang diperoleh dalam sesebuah negara khususnya di Malaysia, kerana masyarakat boleh merasai kesenangan dengan kemudahan-kemudahan yang dilakukan oleh kerajaan. Pembangunan yang dilakukan dalam sesebuah negara juga menggambarkan status kemajuan sesebuah negara tersebut. Di Malaysia salah satu pembangunan yang menjadi kebanggaan masyarakat di negara ini ialah dengan terbinanya menara berkembar PETRONAS dan menara Kuala Lumpur City Centre di Kuala Lumpur. Oleh hal yang demikian, kemajuan pembangunan mampu dikecapi oleh setiap Negara yang aman damai. Rakyat yang bersatu padu menyumbang kepada pembangunan ekonomi 
yang pesat. Kegiatan ekonomi yang berjalan lancar dan cepat telah merubah struktur muka alam yang pada awalnya dipenuhi oleh kehijauan alam flora dan fauna kini menjadi pembangunan. Bangunan yang dibina daripada konkrit tersergam indah dan menjadi pencakar langit menandakan kepesatan pembangunan yang berlaku. Hal ini terdapat di dalam petikan:

Petikan 8

"Seratus tahun dulu, ketika Kuala Lumpur ditemui, tidak ada anak peribumi yang berpeluang menyaksikan kawasan sekitar dari atas. Tidak ada yang tahu dan menyangka bahawa kawasan itu akan sesibuk sekarang. Kalaupun berpeluang, yang dilihat waktu itu hanyalah daun-daun pokok dan sungai mengular jernih. Ketika itu dapat dikesan manusia, bot, rusa dan buaya."

(A. Samad Said, 1985)

Berdasarkan petikan di atas jelas menunjukkan kepesatan pembangunan yang berlaku di Kuala Lumpur pada masa kini jika dibandingkan pada suatu ketika dahulu hanya dipenuhi dengan hutan rimba. Watak Ehran yang mengungkapkan dialog tersebut berasa bangga dan kagum dengan kemajuan yang berlaku di negaranya. Oleh hal yang demikian, pembangunan dalam sesebuah negara sangat penting untuk menggambarkan keadaan negara tersebut maju dan berkembang dengan pesat serta dipandang tinggi oleh semua lapisan masyarakat di seantero dunia. Dulu dan sekarang jauh perbezaannya apabila melihat tahap kemajuan dan kemodenan negara kita khususnya ibu kota Kuala Lumpur yang semakin berkembang maju dan kemajuan ini dapat dirasai oleh semua masyarakat di Malaysia kerana terdapatnya pelbagai kemudahan-kemudahan atau infrastruktur yang canggih dan memenuhi kehendak masyarakat setempat. Dalam konteks ini, maka jelaslah bahawa kepesatan pembangunan yang dicapai oleh sesebuah negara maju seperti Malaysia, akan terkenal di seantero dunia oleh dek kemajuan yang dicapai dalam pelbagai bidang.

Kemajuan ekonomi akan dikecapi oleh masyarakatnya apabila wujudnya kestabilan politik. Kesinambungan daripada keamanan negara serta kemajuan pemikiran rakyat yang mendiami sesebuah negara itu mampu mengubah segala-galanya kepada keadaan yang lebih baik. Kepesatan pembangunan yang berlaku di negara ini mencerminkan bahawa rakyat telah melakukan transformasi dari pelbagai sudut seperti meningkatkan taraf keintelektualan diri sehinggakan mampu membina sebuah negara yang pesat membangun. Dalam konteks ini, pendekatan teori sosiologi ini sangat bertepatan digunakan untuk mengaplikasikan isu yang diutarakan dalam topik perbincangan tersebut.

Selain itu juga, aspek ekonomi menerusi novel Hujan Pagi pengarang jelas menggambarkan tentang kepentingan wang ringgit. Wang ringgit mempunyai peranan penting dalam kehidupan seharian terutamanya bagi meneruskan kelangsungan hidup. Namun, wang juga tidak mampu untuk membeli harga sebuah kasih sayang. Dalam novel Hujan Pagi menggambarkan sikap Idrus yang bekerja keras dan berusaha bersungguh-sungguh untuk melihat anak dan isterinya dapat memakai pakaian baru, dikurniakan kesihatan yang baik seperti anak dan isteri 
orang lain. Perancangan untuk mengubah taraf hidup memerlukan usaha dan pengorbanan yang tinggi agar hasrat yang diimpikan tercapai. Hal ini dapat dibuktikan menerusi petikan cerpen di bawah:

Petikan 9

Idrus, penambang itu, menguitkan dayungnya pada kaki seluar Lajis. Dia tahu manusia berkhayal. Orang tua itu ketawa bila Lajis tersentak. Dia turun berhatihati ke dalam perahu itu selepas seorang perempuan bersama anaknya duduk resah. Dia duduk di hadapan wanita itu, mendongak melihak Idrus. "Saya suka dayung," katanya, merasa-rasa ekor seluarnya yang sedikit basah. "Tapi, sekarang orang lebih memilih tali kipas," kata Idrus. "Hari ini untunglah Munif tak keluar," kata orang tua itu. "Jika tidak ini memang rezekinya."

(A. Samad Said, 1992)

Menerusi petikan tersebut, pengarang menggambarkan terhadap watak Idrus yang berusaha keras untuk mengubah cara hidup mereka sekeluarga. Dia sentiasa bekerja keras untuk menyara kehidupan dalam menyempurnakan pakai, makan dan minum keluarganya. Hal ini kerana, dia bersungguh-sungguh untuk menjadikan keluarganya hidup dalam keadaan sempurna dan memenuhi keperluan hidup yang baik. Dalam konteks ini, wang ringgit perlu dicari dengan mengerjakan sesuatu pekerjaan dengan bersungguh-sungguh untuk menjamin sebuah kehidupan yang sempurna, terutamanya apabila seseorang itu hidup berumah tangga.

Wang merupakan salah elemen penting dalam diri manusia. Setiap manusia yang normal akalnya menjadikan wang sebagai pelengkap dalam kehidupan. Wang diperolehi melalui pelbagai cara dan aspek. Antaranya melalui perniagaan, pertanian dan urusan perdagangan sama ada dalam dan luar negara. Lantaran itu, hasil wang yang diperoleh dijadikan sumber pendapatan yang penting dalam meneruskan kehidupan seharian. Dalam konteks ini, maka wang adalah elemen penting kepada manusia untuk meneruskan kelangsungan hidup untuk memperoleh kehendak dan keperluan dalam diri mereka. Rentetan daripada itu, jelas menggambarkan masyarakat memerlukan sumber pendapatan yang mencukupi bagi meneruskan kehidupan yang sejahtera. Menerusi pendekatan sosiologi ini, maka wang juga melibatkan fenomena yang berlandaskan kepada masyarakat dan kemasyarakatan dalam sesebuah kehidupan manusia.

Selain itu, dalam novel Daerah Zeni, pengarang jelas menggambarkan tentang perdagangan bijih. Sudah sedia maklum, perdagangan bijih timah ini dijalankan sejak zaman dahulu lagi. Pada zaman penjajahan British ke negara kita lagi, perdagangan bijih timah ini diusahakan oleh masyarakat setempat. Masyarakat Melayu sudah sinonim dengan pekerjaan yang mengusahakan perdagangan bijih timah untuk mencari hasil pendapatan untuk meneruskan kelangsungan hidup mereka. Oleh hal yang demikian, perlombongan merupakan salah satu cabang ekonomi yang ada pada masa kini mahupun suatu ketika dahulu. Penduduk bekerja sebagai pelombong bagi menyara kehidupan dan meningkatkan taraf ekonomi diri seperti perlombongan bijih, emas, mahupun bahan bakar seperti petroleum dan gas asli. Hal ini dapat dijelaskan dalam petikan: 
Petikan 10

"Tidak mustahil juga Raja Dabet lulus menyeludup ke kawasan lombong di Pantai Rusa, dan sempat menyeludup keluar sekampit dua bijih untuk ditukarkannya dengan peluru dengan pedagang rasia dari Melaka.

(A. Samad Said, 1985)

Berdasarkan petikan di atas jelas menunjukkan bahawa terdapat kegiatan ekonomi yang berlaku iaitu perlombongan bijih. Terdapat watak yang bernama Raja Dabet telah menyeludup masuk ke kawasan perlombongan bagi mendapatkan bijih dan ditukarkan kepada pedagang yang ada ketika itu. Di sini jelas kegiatan ekonomi telah berlaku bagi memenuhi keperluan semasa dalam menyara kehidupan. Berdasarkan gambaran tersebut, fenomena perdagangan bijih timah telah diusahakan oleh penduduk setempat. Fenomena ini difokuskan kepada penduduk setempat yang mengusahakan pekerjaan melombong bijih timah untuk mendapatkan hasil pendapatan. Ada kalanya, segelintir penduduk setempat mengambil kesempatan ke atas diri orang lain untuk kepentingan diri sendiri. Oleh hal tersebut, pekerjaan mengusahakan bijih timah oleh pendudukan tempatan ketika itu boleh mengubah corak hidup mereka dan dengan aktiviti tersebut boleh meningkatkan taraf hidup dan punca rezeki kepada mereka. Dalam konteks ini, jelas memperlihatkan tentang kepentingan mengusahakan bijih timah oleh penduduk di sesuatu tempat untuk membuktikan bahawa sumber ekonomi masyarakat dan negara hasil daripada aktiviti pekerjaan melombong bijih timah. Menurut Hamidah Abdul Rahman, Muhammad Daud dan Norlin Ahmad (2009), pembangunan ekonomi berkait dengan kualiti hidup masyarakat, kemampuan menyelesaikan masalah kemiskinan keadaan alam sekitar yang bersih dan kemajuan sosial yang lain. Seterusnya, menurut Hendri Hermawan Adinugraha (2013), ekonomi seharusnya menjadi harapan yang mampu menyelesaikan permasalah dan memberi kebaikan kepada rakyat. Sebagai kesimpulannya, aspek ekonomi harus dititikberatkan dalam sistem pembangungan negara bagi mewujudkan sebuah negara yang sejahtera dan stabil dari segi ekonominya.

\section{Petikan 11}

"Akhbar kita ini bukan saja terpaksa bersaing untuk hidup dari segi perniagaannya. Itu memang sudah lama kita lakukan. Akhbar kita juga terpaksa bertahan atau belajar bertahan daripada dihancurkan," kata Lokman.

(A. Samad Said, 1985)

Petikan di atas merupakan contoh realiti kehidupan masyarakat yang terpaksa bekerja keras untuk mendapatkan keperluan harian demi meneruskan kelangsungan hidup. Sektor ekonomi merupakan pemangkin kepada kepesatan pembangun dan kesejahteraan rakyat bagi memenuhi keperluan dan kemudahan dalam menjalani kehidupan. Pihak kerajaan khususnya perlu berusaha keras untuk menjana kegiatan ekonomi baru bagi menampung keperluan yang dituntut oleh setiap golongan rakyat. Kegiatan perdagangan khasnya merupakan suatu sektor yang berkembang sejak dahulu lagi dan wujud dalam masyarakat untuk memberi dan memenuhi keperluan kehidupan. Umumnya perdagangan bijih yang wujud 
sejak kedatangan pihak Inggeris ke tanah Melayu telah membuka peluang baru untuk diceburi masyarakat ketika itu.

\subsection{Kesimpulan}

Justeru, A. Samad Said tidak asing lagi dalam dunia penulisan novel di negara ini. Setiap jalan cerita dalam setiap novel yang dihasilkan mampu membentuk pemikiran masyarakat untuk mengangkat karya beliau ke arah yang lebih baik. Aspek masyarakat dan kemasyarakatan juga sering dibincangkan dalam novel beliau, khususnya dalam novel Hujan Pagi dan Daerah Zeni. Dalam konteks ini, beliau bijak mengutarakan permasalahan sosial yang berlaku dalam kehidupan sesebuah masyarakat sehinggakan beliau mampu untuk memupuk jiwa masyarakat setempat menjalani sebuah kehidupan yang lebih sempurna dengan mengamalkan nilai-nilai moral yang baik. Hal ini dikatakan demikian kerana nilai moral mampu memberi pendedahan yang baik kepada para pembaca. Dengan menerapkan intipati yang bersesuaian dengan kehidupan masyarakat setempat, novel karya A. Samad Said mampu membuatkan masyarakat lebih rasional dalam membuat pertimbangan. Hal ini berlaku demikian kerana A. Samad Said menghasilkan karya yang memberi didikan mahupun pegangan menerusi sikap atau kelakuan diukur dari segi baik dan buruk. Kesannya, sesebuah komuniti mampu memanifesto kebudayaannya, keagamaan dan falsafah dalam kehidupan seharian mereka.

\section{Rujukan}

A. Samad Said. (1992). Hujan Pagi. Kuala Lumpur: Dewan Bahasa dan Pustaka.

A. Samad Said. (1985). Daerah Zeni. Kuala Lumpur: Dewan Bahasa dan Pustaka.

Akhmad Fauzi. (2006). Ekonomi Sumber Daya Alam dan Lingkungan. Jakarta: PT Gramedia Pustaka Utama.

Amiruddin Idris. (2018). Ekonomi Publik. Yogyakarta: Deepublish.

Dani Manesah. (2017). Aspek Sosial Budaya Pada Filem Mutiara Hati Dari Toba Sutradara William Atapary. Jurnal Proporsi. 2 (2), 177-185.

Faziela Abu Bakar@Che Din dan Nik Rafidah Nik Muhamad Affendi (2016). Unsur Konflik dalam Novel Remaja Terpilih. Jurnal Pendidikan Bahasa Melayu. 6 (1), 52-63.

H. Ibrahim Lubis. (1982) Agama Islam: Suatu Pengantar. Jakarta Timur: Ghalia Indonesia.

Halis Azhan Mohd Hanafiah (2014). Dinamika Tema Dalam Novel Remaja Di Malaysia. Sekolah Pengajian Siswazah, ljazah Doktor Falsafah, Universiti Putra Malaysia, Serdang.

Hamidah Abdul Rahman, Muhammad Daud dan Norlin Ahmad. (2009). Pembangunan Ekonomi Dalam Hubungan Etnik. Skudai, Johor: UTM Press. 
Hendri Hermawan Adinugraha. (2013). Norma dan Nilai dalam IImu Ekonomi Islam. Jurnal Media. 21 (1), 49-59.

Kamariah Kamarudin (2017). Mau'izah Remaja dalam Novel Satu Bulan Tiga Bintang Karya Ummu Hani Abu Hassan. Persidangan Antarabangsa Sains Sosial dan Kemanusiaan Kali ke-2 (PASAK 2017), 26-27 Apr. 2017, Pusat Konvensyen Kolej Universiti Islam Antarabangsa Selangor.

Kamaruzzaman Abdul Kadir. (1965). Nasionalisme Dalam Puisi Melayu Moden. Kuala Lumpur: Dewan Bahasa dan Pustaka.

Mit Witjaksono. (2009). Pembangunan Ekonomi dan Ekonomi Pembangunan: Telaah Istilah dan Orientasi dalam Konteks Studi Pembangunan. Jurnal Ekonomi dan Studi Pembangunan. 1 (1), 3-12.

Nurhamizah Hashim (2015). Psikologi Keperluan Remaja dalam Novel-Novel Remaja Hadiah Sastera Kumpulan Utusan (HSKU). Akademi Pengajian Melayu, Universiti Malaya.

Ranjabar, Jacobus. (2006). Sistem Sosial Budaya Indonesia Suatu Pengantar. Bandung: Ghalia Indonesia

Rosnani Md Zain dan Nik Rafidah Nik Muhamad Affendi (2019). Unsur Sains dan Sastera dalam novel remaja terpilih meneliti unsur sains dan sastera yang terdapat dalam novel remaja terpilih. Journal of Malay Language, Education and Literature. Jilid 10, 166-182.

Sayyid Qutb. 1983. al-Mustaqbal li hadha al-Din. Kaherah: Dar al-Syuruq.

Siti Khariah Mohd Zubir dan Nur Denna Binti Samsudin (2016). Analisis Watak dan Perwatakan dalam Novel Sejambak Bakti karya Rejab FI. International Seminar on Generating Knowledge Through Research, UUM-UMSIDA, 25-27 October 2016, Universiti Utara Malaysia, Malaysia. 